\title{
Öğretmenlerin Disleksili Öğrencilere Yönelik Öğretim Tutumları Ölçeği'nin Geçerlik ve Güvenirlik Çalışması
}

DOI: 10.26466/opus.969139

*

\author{
Özlem Altındağ Kumaş* - A.Emel Sardohan Yıldırım ${ }^{* *}$ \\ * Dr. Öğr. Üyesi, Dicle Üniversitesi,Eğitim Fakültesi, Diyarbakır/Türkiye \\ E-Posta: ozlemmaltindag@gmail.com \\ ORCID: $\underline{0000-0002-6104-2381}$ \\ ** Dr. Öğr. Üyesi, Akdeniz Üniversitesi,Eğitim Fakültesi, Antalya/Türkiye \\ E-Posta: emelsardohan@gmail.com \\ ORCID: 0000-0002-2393-299X
}

Öz

Öğretmenler disleksili öğrencilerin öğretim süreçlerinde kritik rol oynamaktadır. Bu araştırmanın amacı "Öğretmenlerin Disleksili Öğrencilere Yönelik Öğretim Tutumları Ölçeği"nin (The Scale of Teachers Attitudes toward Teaching Students with Dyslexia) Türkçe uyarlamasının, geçerlilik ve güvenilirlik çalışmalarının yapılmasıdır. Araştırmaya 279 sınıf öğretmeni katılmıştır. Araştırmada katılımcıların "Öğretmenlerin Disleksili Öğrencilere Yönelik Öğretim Tutumları Ölçeği"ni doldurmalar istenmiştir. Ölçeğin geçerliliğini belirlemek için kapsam, yapı, ayırt edici ve yordama geçerliği analizleri yapılmış; güvenilirliğini belirlemek içinse iç tutarlılık Cronbach Alfa katsayısı hesaplanmıştır. Yapılan analizlerin sonucunda DFA sonuçlarına göre ölçeğin üç faktörlü bir yapısının olduğu tespit edilmiştir. Buna göre ölçeğin birinci boyutu; Bireyselleştirilmiş Öğretim Yöntemi, ikinci boyutu; Öğretim Materyalleri ve Değerlendirme Yöntemlerinin Uyarlanması ve üçüncü boyutu ise Uzmanlar ile İşbirliğidir. Güvenirlik analizleri sonucunda ölçeğin geneli ve alt ölçekler için hesaplanan iç tutarlık katsayıları birinci faktör için .90, ikinci faktör için 84 ve üçüncü faktör için 93 olarak bulunmuştur. Analizler sonucunda araştırmacılar tarafindan Türkiye'de kullanılabilecek geçerli ve güvenilir bir araç olduğu belirlenmiştir.

Anahtar Kelimeler: Disleksili Öğrenci, Disleksi Öğretim Tutum Ölçeği, Geçerlik, Güvenirlik. 


\title{
Validity and Reliability Analyses of the The Scale of Teachers Attitudes toward Teaching Students with Dyslexia
}

*

\begin{abstract}
Teachers have a critical role in the teaching processes of students with dyslexia. The purpose of this research is to conduct validity and reliability studies of the Turkish version of The Scale of Teachers Attitudes toward Teaching Students with Dyslexia. 279 classroom teachers participated in the research. In the study, participants were asked to fill in the "Teaching Attitudes Scale of Teachers Towards Students with Dyslexia". Content, structure, discriminant and predictive validity analyzes were performed to determine the validity of the scale; In order to determine its reliability, the internal consistency Cronbach Alpha coefficient was calculated The results of CFA analysis, it was determined that a scale with a three factor structures. The first dimension of the scale is; Individualized Teaching Method, second dimension; Adaptation of Instructional Materials and Assessment Methods and the third dimension is collaboration with experts. As for the relibility analysis, the internal consistency coefficients calculated for the overall scale and subscales were found to be .90 for the first factor, 84 for the second factor and .93 for the third factor. As a result of the analysis, it has been determined that it is a valid and reliable tool that can be used by researchers in Turkey. The results got showed that the scale can also be used in Turkey.
\end{abstract}

Key Words: Student with Dyslexia, Dyslexia Teaching Attitude Scale, Validity, Reliability. 


\section{Giriş}

21. yüzyılda Amerika Birleşik Devletleri (ABD) ve Avrupa'da tıbbi modelin yerini sosyal modelin almasıyla ve özel eğitimin insan hakları temelinde ele alınmasıyla birlikte genel eğitim sisteminde köklü değişikliklere gidilmiş ve kaynaştırma uygulamaları yürütülmeye başlanmıştır. Kaynaştırma uygulamaları özel gereksinimli olan ve olmayan tüm öğrencilerin aynı ortamlarda eğitim alması ve öğretmenlerin özel gereksinimli öğrencilerin gereksinimlerine uygun uyarlamalar yaparak nitelikli eğitim sunmasıdır (McDonnell ve Hunt, 2014; MEB, 2006). Özel gereksinim kategorisinde zihinsel yetersizlik, otizm spektrum bozukluğu, görme yetersizliği, işitme yetersizliği gibi birçok yetersizlik türü vardır ve bunlardan biri de öğrenme güçlüğüdür. Öğrenme güçlüğü olan öğrenciler kaynaştırma uygulamalarının yürütüldüğ̈̈ sinıflara eğitimlerine devam etmektedirler (Yıldız ve Melekoğlu, 2020). Öğrenme güçlüğü olan öğrencilerin yaygınlığı ile ilgili olarak okula devam eden öğrencilerin \%10-20'sinde özel öğrenme güçlüğü olduğu ve yaklaşık her 10 çocuktan birinde de öğrenme güçlüğünün görüldüğü ortaya konulmuştur (Meslekî Eğitim ve Öğretim Sisteminin Güçlendirilmesi Projesi [MEGEP], 2007). Son yıllarda da öğrenme güçlüğü olan öğrencilerin sayısı giderek artmaktadır (Cakiroglu ve Melekoglu, 2014).

Öğrenme güçlüğü bireyin öğrenme yeteneğinde kritik rol oynayan okuma, yazma ve matematik alanlarının birini veya birkaçını etkilemektedir (Ruhsal Bozuklukların Tanısal ve Sayımsal El Kitabı V, 2014 [Diagnostic and Statistical Manual of Mental Disorders] (DSM-V); Amerika Psikiyatri, Birliği, 2014 [American Psychiatric Association]). DSM-V'te (2014) nörolojik bir bozukluk olarak belirtilen öğrenme güçlüğü çoğunlukla üç farklı kategoride ele alınmaktadır. Bunlar; disleksi (okuma güçlüğü), diskalkuli (matematik güçlüğü) ve disgrafidir (yazma güçlüğü). Disleksi, doğru ve/veya akıcı olarak sözcük tanımada ve zayıf heceleme ve çözümleme yetenekleri nedeniyle karşılaşılan güçlüktür (Güldenoğlu, Kargin ve Ergül, 2016; Soriano-Ferrer ve Echegaray-Bengoa, 2014). Disleksili öğrenciler okuduğunu anlama, sözcükleri doğru isimlendirme, kelimeleri bütün halinde okuyamama, harf-ses ilişkisi kurma gibi güçlükler yaşamaktadırlar (Baydık, 2002; 2011; Baydık, Ergül ve Bahap 
Kudret, 2012). Öğrencilerin yaşadığı bu güçlükler sadece akademik alandaki öğrenmeleri değil aynı zamanda okul başarısını, sosyal ilişkilerini ve toplumsal katılımı da olumsuz etkilemektedir (Colenblander, Ricketts ve Breadmore, 2018; Seçkin Yılmaz ve Erim, 2019). Disleksili öğrencilerin karşılaştıkları bu güçlükler dilin fonolojik bileşeninden kaynaklanmaktadır (Eden, Olulade, Evans, Krafnick ve Alkire, 2016; Seçkin Yılmaz ve Erim, 2019).

Eğitim süreçlerinde disleksili öğrencilerin yaşadığı akademik, sosyal ve toplumsal anlamdaki güçlükler öğretmenlerde bu öğrencilere yönelik düşük başarı beklentisi oluşturmakta (Clark, 1997; Stampoltzis, Tsitsou ve Papachristopoulos, 2018) ve öğrencinin öğretmenleri tarafından etiketlenmesi söz konusu olmaktadır. Etiketleme ise bir grubun belirli özelliklerinden dolayı onlara olumsuz tutumların benimsenmesidir (Dovidio, Major ve Crocker, 2000). Araştırmacılar (Elias, 2014; Jussim ve Harber, 2005) öğretmenlerin disleksili öğrencilerine yönelik tutumlarının olumsuz olduğunda, bu öğrencilerin başarılarının da olumsuz etkilendiğini belirtmektedir. Dahası öğretmenlerin bu öğrencilerin başarılarını da olumsuz bir tutumla değerlendirme eğiliminde oldukları vurgulanmaktadır (Hornstra ve ark., 2010; Krischler ve Pit-ten Cate, 2019). Öğretmenlerle yapılan çalışmalarda (Başar ve Göncü, 2018; Doğan, 2013; Hornstra ve ark., 2010; Wadlington ve Wadlington, 2005) öğretmenlerin disleksi ile ilgili kapsamlı ve yetkin bir bilgiye sahip olmak yerine disleksi hakkında farkındalıklarının olmadığını ve/veya yanlış algılamalara/kavramlara sahip oldukları ortaya çıkmıştır. Disleksili öğrencilere yönelik yanlış algılamalar, kavram yanılgıları ve bilgi eksikliği bu öğrencilerin doğru tanılanmasına, bu öğrencilere yönelik bireyselleştirilmiş öğretim planı hazırlama, öğretim materyalleri uyarlama ve öğrenciyi değerlendirme de ayrıca öğrencinin yetersizliği ile ilgili paydaşlarla işbirliği sürecinde güçlük yaşamalarına ve dolayısıyla özel eğitim süreçlerinin nitelikli yürütülmemesine neden olmaktadır (Güzel-Özmen, 2008; Seçkin Yılmaz ve Erim, 2018; Sümer Dodur ve Altındağ Kumaş, 2021). Bu durumda öğretmenlerin bu özel eğitim süreçlerini olması gerektiği gibi yürütebilecek yeterliğe sahip olmaması hem öğretmenlerin mesleki öz-yeterlik algılarını hem de öğrenme güçlüğü olan öğrencilerin akademik başarılarını olumsuz yönde etkilemektedir (Yıldız ve Melekoğlu, 2020). Oysaki etkili kaynaştırma 
uygulamalarının yürütülme sürecinde disleksili öğrencilerin eğitimlerinde her bir öğrencinin gereksinimlerinin belirlenmesi, bunlara odaklanılması ve buna yönelik planlamalar yapılması gerekmektedir (Kuruyer ve Çakıroğlu, 2017; Martan, Skočić Mihić ve Matošević, 2017). Öğretmenler disleksinin doğasını anladıklarında, disleksi ile ilgili bilgi sahibi olup, farkındalık kazandıklarında disleksili öğrencilerinin gereksinimlerine yönelik eğitimsel müdahaleleri de daha işlevsel planlayacaktır.

Öğretmenlerin disleksili öğrencilerine yönelik tutumları, disleksi ile ilgili bilgilerinden de etkilenmektedir (Krischler ve Pit-ten Cate, 2019; Stampoltzis, Tsitsou ve Papachristopoulos, 2018). Öğretmenlerin disleksi ile ilgili tutumları soyut olmasına rağmen, disleksili öğrencilere etkisi (örn. öğrencinin düşük akademik başarısı, öğretmenlerin eğitimsel süreçlerde uyarlama yapmaması) somut olarak görülmektedir. Dolayısıyla öğretmenlerin disleksi ile ilgili tutumları sadece öğretmenlerin öğretimsel sürecini değil aynı zamanda disleksili öğrencilerin eğitimsel süreçlerini ve akademik başarılarını da etkilemektedir. $\mathrm{Bu}$ araştırmada uluslararası alanyazında sınıf öğretmenlerinin disleksili bireylere yönelik tutumlarının belirlenmesinde kullanılan “Öğretmenlerin Disleksili Öğrencilere Yönelik Öğretim Tutumları Ölçeği" nin (The Scale of Teachers Attitudes toward Teaching Students with Dyslexia) Türkçe uyarlamasının, geçerlilik ve güvenilirlik çalışmalarının yapılması amaçlanmıştır. Disleksi ile ilgili ulusal alanyazındaki araştırmaları dikkate alarak yapılan bu çalışma ile sınıf öğretmenlerinin disleksili öğrencilere yönelik tutumlarının belirlenmesinde alan yazındaki boşluğa katkı sağlayacağ düşünülmektedir.

\section{Yöntem}

$\mathrm{Bu}$ araştırma bir ölçek uyarlama çalışmasıdır. Çalışma grubu ve veri toplama aracının özellikleri ile ölçeğin Türkçeye uyarlanma süreci hakkındaki bilgilere aşağıda yer verilmiştir.

Çalışma Grubu: Araştırma 2020-2021 eğitim-öğretim yılı içerisinde Türkiye'nin çeşitli illerinde görev yapan 279 sınıf öğretmeninden oluşan 
bir çalışma grubu ile yürütülmüştür. Çalışma grubundaki öğretmenlerin 179'ü (\%64) kadın, 100'ü (\%36) erkektir. Çalışma grubundaki öğretmenlerin hizmet sürelerine bakıldığında 1-10 yıl arasında 152 öğretmenin, 10-20 yıl arasında 69 öğretmenin, 20 yıl ve daha fazla 58 öğretmenin olduğu görülmektedir.

\section{Veri Toplama Araçları}

Demografik Bilgi Formu: Öğretmenlerle ilgili demografik özellikler için araştırmacılar tarafından geliştirilmiş olan "Kişisel Bilgi Formu" uygulanmıştır. Bu form öğretmenin cinsiyeti, yaşı, meslekte çalı̧̧ma süresi, gibi bilgileri içermektedir.

\section{Öğretmenlerin Disleksili Öğrencilere Yönelik Öğretim Tutumları Ölçeği} (DYTÖ): Öğretmenlerin Disleksili Öğrencilere Yönelik Öğretim Tutumları Ölçeği, Martan, Skočić Mihić ve Matošević (2017) tarafından geliştirilmiştir. Bu ölçek, öğretmenlerin disleksili öğrencilere yönelik öğretim tutumları inceleyen üç alt faktörden ve 20 maddeden oluşmaktadır. Ölçekte, 1= Katılmıyorum, 2 - Az katılıyorum, 3- Zaman zaman katılıyorum, 4 - Çoğunlukla katıliyorum, 5 - Tamamen katılıyorum şeklinde 5'li likert tipi bir derecelendirme kullanılmıştır.

İlk faktör "bireyselleştirilmiş öğretim yöntemi" faktörüdür ve altı maddeden oluşmaktadır. $\mathrm{Bu}$ faktör disleksili öğrencilerin bireyselleştirilmiş öğretimini tanımlayan ifadeleri içermektedir. İkinci faktör 6 maddeden oluşan "öğretim materyalleri ve değerlendirme yöntemlerinin uyarlanması" faktörüdür. Bu faktörde disleksili öğrencilere yönelik öğretim materyallerinin ve değerlendirme yöntemlerinin çocuğa uyarlanmasına yönelik ifadelere yer verilmiştir. Üçüncü faktör 8 maddeden oluşmakta ve "uzmanlar ile işbirliği" olarak adlandırılmaktadır. Bu faktör, olumlu sınıf atmosferinin yaratılmasını ve disleksili öğrencilerin gelişimi için ebeveynler, öğretmenler ve diğer uzmanlar arasında işbirliğinin önemini açıklayan ifadeleri içermektedir.

Orijinal ölçeğin Cronbach alfa güvenirlik katsayısı birinci alt ölçek için 0,81, ikinci alt ölçek için 0,72 ve üçüncü alt ölçek için 0,79'dur. Bireyselleştirilmiş öğretim yöntemleri faktörü, öğretim materyalleri ve değerlendirme yöntemlerinin uyarlanması $(r=0.620, p<0.001)$ ile 
uzmanlar ile işbirliğ $\mathrm{i}(\mathrm{r}=0.508, \mathrm{p}<0.001)$ faktörleri arasında güçlü bir ilişki bulunmuştur. Ölçekte her bir maddeye öğretmenlerin ne kadar katıldıkları analiz edilmekte toplam puan kullanılmamaktadır.

\section{Ölçeğin Uyarlanması ve Veri Toplama}

DYTÖ'nün Türkçeye uyarlama sürecindeki ilk adım ölçeği geliştiren araştırmacılar ile iletişime geçilerek gerekli iznin alınması olmuştur. Araştırmacılar ölçeğin Türkçeye uyarlanmasına onay verdiğini bildiren bir mail yazmıştır. Bu cevapla birlikte, Özel Eğitim alanından iki uzman, Eğitim Bilimleri alanından iki uzman ve Ölçme-Değerlendirme alanlarından bir uzman olmak üzere toplamda beş uzman tarafından ölçek maddelerinin İngilizceden Türkçeye çevirisi yapılmıştır. Türkçeye çevrilen form İngilizce alanında uzman üç kişi tarafından İngilizceye geri çevrilmiştir. Daha sonra yapılan çeviriler karşılaştırılarak her bir madde için ilgili maddeyi en iyi yansıtacak Türkçe ifadeler belirlenmeye çalışılmıştır. Uzmanlardan alınan görüşler çerçevesinde araştırmacılar tarafından son hali verilen Türkçe Formunun anlam ve dilbilgisi açısından incelenmesi için Türkçe eğitimi alanında uzman olan akademisyenin görüşüne sunularak ölçeğe son hali verilerek uygulamaya geçilmiştir.

\section{Uygulama}

Araştırma, gerçekleştirildiği dönemde yaşanan COVID-19 pandemisi yüzünden online ortamda gerçekleştirilmiştir. Tüm veri toplama araçlarındaki sorular "Google formlar"a işlenmiş ve paylaşılabilir bir bağlantı oluşturulmuştur. Google formlar üzerinden tasarlanan ölçekler dört hafta boyunca veri alımı için açık bırakılmış ve dört haftanın sonunda form veri girişine kapatılmıştır. Google forms'da anket tasarlanırken bütün sorular için doldurulması gerekli seçeneği işaretlendiği için doldurulan formlarda eksik veriye rastlanmamış ve dolayısıyla hiçbir form geçersiz sayılmamıştır. 


\section{Veri Analizi}

DYTÖ'nün Türkçe formunun yapı geçerliği doğrulayıcı faktör analizi (DFA) ile test edilmiştir. DFA için LISREL 8.54 paket programindan yararlanılmıştır.

Bu kapsamda ölçeğin yapı geçerliliği ve ölçüt geçerliliği incelenmiş, ayrıca iç tutarlılık katsayısı analizleri ile toplam puanları arasındaki ilişkiler incelenerek güvenilirlik analizleri gerçekleştirilmiştir. Analizlere geçilmeden önce tek ve çok yönlü uç değerler incelenmiş ve maddelerin tek ve çok değişkenli normallik varsayımlarını da sağladığı görülmüştür (Tabacnick ve Fidell, 2013).

Doğrulayıcı faktör analizi sonuçlarını geçerli kabul edebilmek için modele ait uyum iyiliği indekslerinin yeterlilik göstermesi gerekmektedir. Uyum İyiliği İndeksi (Goodness of Fit Index, GFI), Normlaştııılmış Uyum İndeksi (Normed Fit Index, NFI), Göreli Uyum İndeksi (Relative Fit Index, RFI), Karşılaştırmalı Uyum İndeksi (Comparative Fit Index, CFI) ve Fazlalık Uyum İndeksleri'nin (Incremental Fit Index, IFI) 0.90'dan büyük değerlerde olması yeterli düzeyde uyumun olduğu, değerlerin 0 'a yaklaşmasının kötü, 1'e yaklaşmasının mükemmel uyum gösterdiği, Standartlaştırılmış Ortalama Hataların Karekökü (Standardized Root Mean Square Residuals, SRMR) ve Yaklaşık Hataların Ortalama Karekökü'nün (Root Mean Square Error of Approximation, RMSEA) ise 0.05 ten küçük olmasının iyi uyumu, 0.10 'in altında olması ise kabul edilebilir bir uyum iyiliğini, ki-kare değerinin serbestlik derecesine oranın ise 5'in altında olmasının iyi uyumu gösterdiği belirtilmektedir (Tabachnick ve Fidell, 2013). Doğrulayıcı faktör analizi için uyum indeksleri incelendiğinde ki-kare değerinin serbestlik derecesine oranının $(398.93 / 167=2.388) 5$ 'in altında yeterli düzeyde bir değere sahip olduğu görülmüştür. Diğer uyum indeksleri incelendiğinde RMSEA=0.107, $\mathrm{SRMR}=0.05, \mathrm{NFI}=0.96, \mathrm{RFI}=0.95, \mathrm{CFI}=0.97$ ve $\mathrm{IFI}=0.97$ olarak bulunmuştur. $\mathrm{Bu}$ değerlerin 0.95 'ten yüksek olması mükemmel uyum değerlerine sahip olduğunu göstermektedir. SRMR'nin $0.5^{\prime}$ ten küçük ve RMSEA'nın ise $0.05 \leq$ RMSEA $\leq .0 .10$ arasında olması kabul edilebilir uyum düzeyinde olduğunu işaret etmektedir. Doğrulayıcı faktör analizi sonucunda elde edilen uyum iyiliği indeksleri incelendiğinde modelin uyumlu olduğu görülmektedir. Aşağıda ölçeğin faktörleri ve maddelerine 
ilişkin standartlaştırılmış parametre tahminlerinin yer aldığı model Şekil 1 'de sunulmuştur.

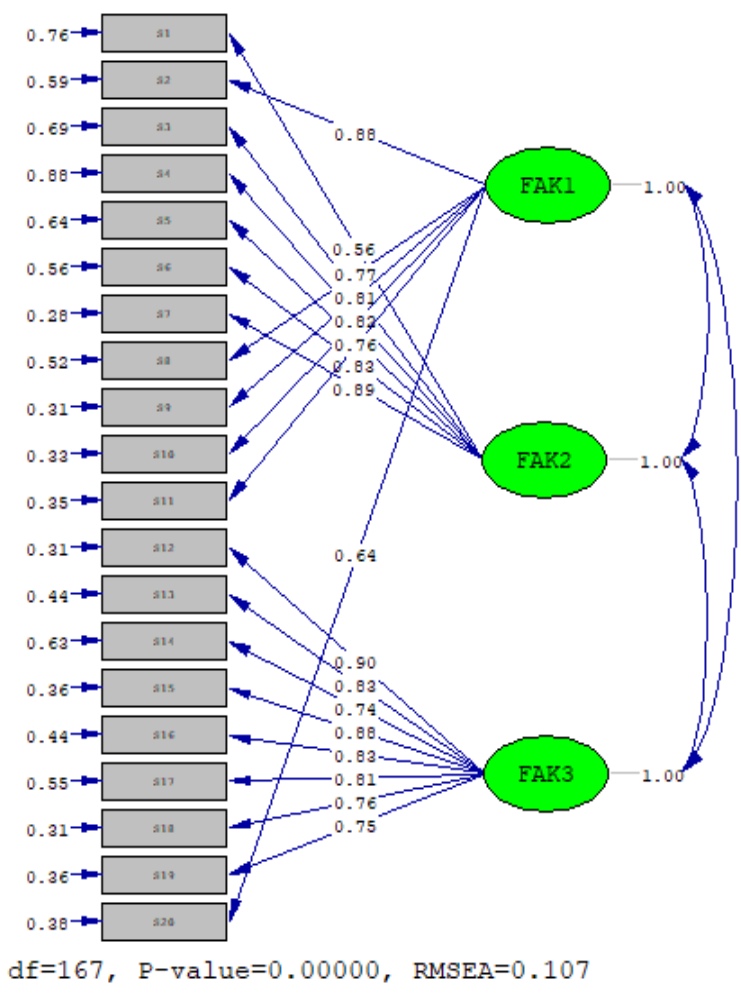

Şekil 1. DFA'dan Elde Edilen Ölçme Modeli

\section{Güvenirlik}

DYTÖ'nün Türkçe formu ile elde edilen ölçümlerin güvenirliği ölçeğin orijinal formunda olduğu gibi Cronbach alfa iç tutarlılık katsayısı ile hesaplanmıştır. Hesaplanan iç tutarlılık katsayıları; bireyselleştirilmiş öğretim yöntemi” faktörü için .90, “öğretim materyalleri ve değerlendirme yöntemleri" faktörü için .84, "uzmanlar ile işbirliği" faktörü için .93 olarak bulunmuştur. Bu bulgular doğrultusunda ölçeğin tüm faktörlerine ilişkin güvenirliğin iyi düzeyde (>.70) olduğu söylenebilir (George ve Mallery, 2003). 
Tablo 1. DYTÖ'ye ait Madde Analizleri, R2 ve t Değerleri

\begin{tabular}{lcccc}
\hline Madde Sırası & Madde & $\mathbf{r}_{\mathbf{j} \mathbf{x}}$ & $\mathbf{t}$ & $\mathbf{R}^{\mathbf{2}}$ \\
\hline & 2 & .73 & 14.54 & .57 \\
Bireyselleştirilmiş Öğretim & 8 & .71 & 14.01 & .54 \\
Yöntemi & 9 & .78 & 16.50 & .67 \\
& 10 & .78 & 16.37 & .67 \\
& 11 & .77 & 15.77 & .63 \\
\hline \multirow{3}{*}{ Ŏgretim Materyalleri ve } & 20 & .70 & 13.36 & .51 \\
Değerlendirme Yöntemleri & 1 & .54 & 9.50 & .30 \\
& 3 & .65 & 12.81 & .48 \\
& 4 & .51 & 9.81 & .31 \\
& 5 & .66 & 13.10 & .49 \\
& 6 & .70 & 14.08 & .55 \\
& 7 & .81 & 17.51 & .74 \\
\hline & 12 & .82 & 17.06 & .70 \\
Uzmanlar ile İşbirliği & 13 & .75 & 15.38 & .61 \\
& 14 & .59 & 12.92 & .48 \\
& 15 & .79 & 16.75 & .68 \\
& 16 & .76 & 15.66 & .63 \\
& 17 & .70 & 14.26 & .55 \\
& 18 & .74 & 15.50 & .62 \\
\hline
\end{tabular}

Ölçekteki maddelerin ayırt edicilik düzeylerini belirlemek amacıyla düzeltilmiş madde toplam korelasyonları (rjx) hesaplanmış ve Tablo 1'de sunulmuştur. Madde toplam korelasyonun .30'un üzerinde bir değere sahip olması madde ayırt ediciliği için bir kanıt oluşturmaktadır (Erkuş, 2012). Tablo 1'e bakıldığında, tüm madde korelasyonlarının .30'un üzerinde olduğu görülmektedir. Ayrıca, DFA sonuçları maddelerin $R^{2}$ değerlerinin 0.31-0.74 arasında, $\mathrm{t}$ değerlerinin ise 9.50-17.51 arasında olduğunu ve tüm maddeler için tüm yolların anlamlı olduğunu ( $t_{i}>1.96$ ve $\left.\mathrm{p}_{\mathrm{i}}<0.05\right)$ göstermiştir. Buna göre, ölçeğin Türkçe formunun ayırt edici maddelerden oluştuğu söylenebilir.

\section{Tartışma ve Sonuç}

Öğretmenlerin sınıftaki uygulamaları, öğrenme ve öğretme konusundaki tutumlarından güçlü bir şekilde etkilenmektedir. Öğretmenlerin öğrenme güçlüğü yaşayan öğrencilerin öğrenimine ilişkin tutumları değişmedikçe, bu öğrencilere yönelik öğrenim uyarlamalarının da değişmesi beklenmemektedir (Hornstra ve ark., 2010). Bu ölçek öğretmenlerin 
disleksili öğrencilere yönelik öğretim tutumları hakkında bilgi edinmek için uyarlanmıştır.

Bu çalışmanın amacl, Martan, Skočić Mihić ve Matošević (2017) tarafından geliştirilen “Öğretmenlerin Disleksili Öğrencilere Yönelik Öğretim Tutumları Ölçeği”ni Türkçe'ye uyarlamak ve ölçeğin geçerlilik güvenirlik analizlerini inceleyerek, ölçeği ulusal yazına kazandırmaktır. Ölçek uyarlama çalışması sırasında yapılan analizler sonucunda, 3 boyutlu (bireyseleştrilmiş öğretim yöntemi, öğretim materyallerinin ve değerlendirme yöntemleri, uzmanlar ile iş birliği) DYTÖ ölçeğinin Türk örnekleminden elde edilen veri ile uyum içinde ve maddelerin tümünün özgün ölçek ile benzer biçimde aynı faktörler altında toplandığı, tüm maddelerin alt ölçek toplam puanlarına katkısının anlamlı olduğu ve her maddenin faktör yüklerinin de kabul edilebilir düzeyde olduğu bulunmuştur. Bu bağlamda, ölçeğin ulusal yazında kullanılmasında bir sakınca bulunmadığı görülmektedir.

DYTÖ'nün güvenirliği Cronbach alfa iç tutarlık katsayısı ile incelendiğinde hesaplanan iç tutarlık katsayılarının .84 ile .93 arasında değiştiği görülmüştür. Güvenirlik katsayısı için esas alınması önerilen ölçüt .70 ve yukarısı olduğundan, elde edilen katsayılar güvenirlik için yeterli kabul edilmektedir (Sipahi, Yurtkoru ve Çinko, 2010). Buna göre, DYTÖ'nün güvenilir ölçümler üreten bir ölçme aracı olduğu ifade edilebilir. DYTÖ'deki madde toplam korelasyonları ölçekteki tüm maddeler için .30'un üzerinde bulunmuştur. Dolayısıyla, ölçek maddelerinin ayırt edicilik düzeylerinin yeterli olduğu söylenebilir (Akbulut, 2010) Araştırmada; geçerlik, güvenirlik ve madde analizi ile ilgili ulaşılan sonuçlar neticesinde DYTÖ'nun Türkçe formunun gerekli/yeterli özelliklere sahip olduğu ve öğretmenlerin disleksili öğrencilere yönelik öğretim tutumları ölçmesi amacıyla kullanılabileceği görülmüştür.

$\mathrm{Bu}$ çalışma bir ölçek geliştirme çalışması olduğu için öğretmen deneyim yılı, cinsiyeti ve hizmetiçi eğitim alma gibi demografik bilgilerine ilişkin farklılıklar incelenmemiştir. Dolayısıyla ileriki çalışmalarda öğretmenlerin demografik bilgileri ve DYTÖ ölçeğinden aldıkları puanlar arasındaki ilişkiler incelenebilir. Çalışmalarda uyarlanan ölçek kullanılarak öğretmenlerinin mesleki gelişimi desteklemek amacıyla planlanacak hizmet içi eğitim çalışmalarına katkı sağlanabilir. Çalışmanın 
önemli bir sınırlılığı verilerin sadece bir şehirde toplanmış olmasıdır. Her ne kadar örneklem sayısı analiz için yeterli olsa da gelecekteki araştırmalarda farklı örneklemlerle ölçeğin güvenirlik ve geçerliğinin tekrar tekrar test edilmesi önerilmektedir. 


\title{
EXTENDED ABSTRACT
}

\section{Validity and Reliability Analyses of the The Scale of Teachers Attitudes toward Teaching Students with Dyslexia}

\author{
Özlem Altındağ Kumaş - A.Emel Sardohan Yıldırım \\ Dicle University-Akdeniz University
}

Academic, and social difficulties experienced by students with dyslexia in the educational process create low expectations of success for these students (Clark, 1997; Stampoltzis, Tsitsou and Papachristopoulos, 2018) and the students are labeled by their teachers. Labeling is the adoption of negative attitudes towards a group due to certain characteristics (Dovidio, Major and Crocker, 2000). Researchers (Elias, 2014; Jussim and Harber, 2005) state that when teachers' attitudes towards their students with dyslexia are negative, their success is also negatively affected. Moreover, it is emphasized that teachers tend to evaluate the success of these students with a negative attitude (Hornstra et al., 2010; Krischler and Pitten Cate, 2019). In the studies conducted with teachers (Başar and Göncü, 2018; Doğan, 2013; Hornstra et al., 2010; Wadlington and Wadlington, 2005), instead of having a comprehensive and competent knowledge about dyslexia, teachers have no awareness of dyslexia and/or misperceptions/concepts.

Teachers' attitudes towards their students with dyslexia are also affected by their knowledge of dyslexia. Although teachers' attitudes towards dyslexia are abstract, its impact on students with dyslexia (eg, students' low academic achievement, teachers' failure to adapt in educational processes) is tangible. Therefore, teachers' attitudes towards dyslexia affect not only the instructional process of teachers, but also the educational processes and academic achievements of students with dyslexia. In this study, it was aimed to carry out validity and reliability studies of the Turkish adaptation of "The Scale of Teachers Attitudes toward Teaching Students with Dyslexia", which is used in the international literature to determine the attitudes of classroom teachers towards individuals with dyslexia. It is thought that this study, which was 
carried out taking into account the studies in the national literature on dyslexia, will contribute to the gap in the literature in determining the attitudes of classroom teachers towards dyslexic students.

The first step in the adaptation process of the scale to Turkish was to get the necessary permission by contacting the researchers who developed the scale. The researchers wrote an e-mail stating that they approved the adaptation of the scale into Turkish. With this answer, the scale items were translated from English to Turkish by a total of five experts, two experts from the field of Special Education, two experts from the field of Educational Sciences and one specialist from the fields of Assessment and Evaluation. The form translated into Turkish was translated back into English by three experts in the field of English. Later, by comparing the translations, it was tried to determine the Turkish expressions for each item that would best reflect the relevant item. In order to examine the Turkish form, which was finalized by the researchers within the framework of the opinions received from the experts, in terms of meaning and grammar, it was presented to the opinion of the academician who is an expert in the field of Turkish education, and the scale was finalized and implemented.

Teachers' practices in the classroom are strongly influenced by their attitudes towards learning and teaching. Unless teachers' attitudes towards the learning of students with learning difficulties change, learning adaptations for these students are not expected to change (Hornstra et al., 2010). This scale was adapted to obtain information about teachers' teaching attitudes towards students with dyslexia.

The aim of this study is to adapt the "Teachers' Attitudes Towards Dyslexic Students Scale" developed by Martan, Skočić Mihić and Matošević (2017) into Turkish and to bring the scale to the national literature by examining the validity and reliability analyzes of the scale. As a result of the analyzes made during the scale adaptation study, it was found that the 3-dimensional (individualized teaching method, teaching materials and evaluation methods, cooperation with experts) ATDS scale was in harmony with the data obtained from the Turkish sample and that all the items were collected under the same factors as the original scale. It was found that the contribution of the items to the subscale total scores was significant, and the factor loads of each item were at an acceptable 
level. In this context, it is seen that there is no harm in using the scale in national literature.

When the reliability of the ATDS was analyzed with the Cronbach's alpha internal consistency coefficient, it was observed that the calculated internal consistency coefficients ranged from .84 to .93 . Since the recommended criterion for the reliability coefficient is .70 and above, the obtained coefficients are considered sufficient for reliability (Sipahi, Yurtkoru, \& Çinko, 2010). Accordingly, it can be stated that ATDS is a measurement tool that produces reliable measurements. The item-total correlations in the ATDS were found to be over .30 for all items in the scale. Therefore, it can be said that the discrimination levels of the scale items are sufficient (Akbulut, 2010). As a result of the results obtained regarding validity, reliability, and item analysis, it was seen that the Turkish form of ATDS has necessary/sufficient features and can be used to measure teachers' teaching attitudes towards dyslexic students.

Since this study is a scale development study, differences in demographic information such as teacher experience years, gender and in-service training were not examined. Therefore, in future studies, the relationships between teachers' demographic information and the scores they get from the ATDS scale can be examined. By using the scale adapted in the studies, it can be contributed to the in-service training studies to be planned to support the professional development of teachers. An important limitation of the study is that the data were collected in only one city. Although the sample size is sufficient for the analysis, it is recommended that the reliability and validity of the scale be tested repeatedly with different samples in future studies.

\section{Kaynakça/References}

Akbulut, Y. (2010). Sosyal bilimlerde SPSS uygulamalarn: Sik kullanilan istatiksel analizler ve açıklamalı SPSS çözümleri. İstanbul: İdeal Kültür Yayıncılık.

American Psychiatric Association. (2014). Manual diagnóstico y estadístico de los trastornos mentales. DSM-5. Diagnostic and statistical manual of mental disorders (5. baskı). Madrid: E. Médica Panamericana.

Başar, M. ve Göncü, A. (2018). Sınıf öğretmenlerinin öğrenme güçlüğüyle ilgili kavram yanılgılarının giderilmesi ve öğretmen görüşlerinin 
değerlendirilmesi. Hacettepe Üniversitesi Eğitim Fakültesi Dergisi, 33(1), 185-206, doi: 10.16986/HUJE.2017027934.

Baydık, B. (2002). Okuma güçlüğ̈̈ olan ve olmayan çocuklarm sözcük okuma becerilerinin karşılaştırılması. (Yayınlanmamış doktora tezi). Ankara Üniversitesi, Eğitim Bilimleri Enstitüsü, Zihin Engelliler Anabilim Dalı, Ankara.

Baydık, B. (2011). Okuma güçlüğü olan öğrencilerin üstbilişsel okuma stratejilerini kullanımı ve öğretmenlerinin okuduğunu anlama öğretim uygulamalarının incelenmesi. Eğitim ve Bilim, 36(162), 301-318.

Baydık, B., Ergül, C. ve Bahap Kudret, Z. (2012). Okuma güçlüğü olan öğrencilerin okuma akıcllı̆̆ sorunları ve öğretmenlerinin bu sorunlara yönelik öğretim uygulamaları. Ilköğretim Online, 11(3), 778-789.

Clark, M. D. (1997). Teacher response to learning disability: A test of attributional principles. Journal of Learning Disabilities, 30, 69-79.

Cakiroglu, O. ve Melekoglu, M. A. (2014). Statistical trends and developments within inclusive education in Turkey. International Journal of Inclusive Education, 18(8), 798-808. http://dx.doi.org/10.1080/ 13603116.2013.836573.

Colenbrander, D., Ricketts, J. ve Breadmore, H. L. (2018). Early identification of dyslexia: Understanding the issues. Language, Speech and Hearing Services in Schools, 49, 817-828.

Doğan, B. (2013). Türkçe ve sınıf öğretmenlerinin okuma güçlüğüne ilişkin bilgileri ve okuma güçlüğü olan öğrencileri belirleyebilme düzeyleri. Okuma Yazma Eğitimi Araştırmaları Dergisi, 1(1) 20-33.

Dovidio, J. F., Major, B. ve Crocker, J. (2000). Stigma: Introduction and overview. In T. F. Heatherton, R. E. Kleck, M. R. Hebl, \& J. G. Hull (Eds.), The social psychology of stigma (p.1-30). New York: Guilford.

Eden, G. F., Olulade, O. A., Evans, T. M., Krafnick, A.J. ve Alkire, D. R. (2016). Developmental dyslexia. In G. Hickok \& S. Small (Eds.), Neurobiology of language (p.815-826). Elsevier: Oxford, UK.

Elias, R. (2014). Dyslexic learners: An investigation into the attitudes and knowledge of secondary school teachers in New Zealand (Doctoral dissertation). University of Auckland, New Zealand.

George, D. ve Mallery, P. (2003). Using SPSS for Windows step by step: A simple guide and reference (4th ed.). London: Pearson Education.

Güldenoğlu, B., Kargın, T. ve Ergül, C. (2016). Ses bilgisi farkındalık becerilerinin okuma ve okuduğunu anlama üzerindeki etkisi: 
Boylamsal bir araştırma. Illköğretim Online, 15(1), 251-272, doi: http://dx.doi.org/10.17051/io.2016.25973.

Güzel-Özmen, R. (2008). Öğrenme güçlüğü olan öğrenciler. Halil İbrahim Diken (Ed.). Özel Gereksinimi Olan Öğrenciler ve Özel Ĕ̆itim (s.333-367). Ankara: Pegem Akademi.

Hornstra, L., Denessen, E., Bakker, J., van den Bergh, L. ve Voeten, M. (2010). Teacher attitudes toward dyslexia: Effects on Teacher expectations and the academic achievement of students with dyslexia. Journal of Learning Disabilities, 43(6), 515-529. https://doi. org/10.1177/0022219409355479.

Jussim, L. ve Harber, K. D. (2005). Teacher expectancies and selffulfilling prophecies: Knowns and unknowns, resolved and unresolved controversies. Personality and Social Psychology Review, 9, 131-155.

Krischler M ve Pit-ten Cate IM. (2019) Pre- and In-Service Teachers' attitudes toward students with learning difficulties and challenging behavior. Front. Psychol, 10, 327. doi: 10.3389/fpsyg.2019.00327.

Kuruyer, H. Y. ve Çakıroğlu, A. (2017). Sınıf öğretmenlerinin özel öğrenme güçlüğü olan öğrencilerin eğitsel değerlendirme ve eğitimsel müdahale sürecinde görüş ve uygulamaları, International Periodical for the Languages, Literature and History of Turkish or Turkic, 12(28), 539-555, DOİ: 10.7827/TurkishStudies.12494.

Martan, V., Mihić, S. S. ve Matošević, A. (2017). Teachers' attitudes toward teaching students with dyslexia, Croatian Journal of Education, 19(3), 7597.

McDonnell, J. ve Hunt, P. (2014). Inclusive education and meaningful school outcomes. Baltimore, Maryland: Paul H. Brooks.

Meslekî Eğitim ve Öğretim Sisteminin Güçlendirilmesi Projesi [MEGEP]. (2007). Çocuk gelişimi ve eğitimi: Öğrenme güçlüğü. Ankara: Milli Eğitim Bakanlığı Yayınları.

Colenbrander, D., Ricketts, J. ve Breadmore, H. L. (2018). Early identification of dyslexia: Understanding the issues. Language, Speech and Hearing Services in Schools, 49, 817-828.

Milli Eğitim Bakanlığı (MEB). (2006). Özel Ĕ̆itim Hizmetleri Yönetmeliği. Ankara: Milli Eğitim Bakanlığı Yayınları.

Seçkin Yılmaz, Ş. ve Erim, A. (2019). Türkiye'de yaşayan yetişkinlerin disleksiye ilişkin bilgi düzeylerinin incelenmesi. Bolu Abant İzzet Baysal Üniversitesi Eğitim Fakültesi Dergisi, 19(3), 1102-1115. 
Soriano-Ferrer, M. ve Echegaray-Bengoa, J. A. (2014). A scale of knowledge and beliefs about developmental dyslexia: Scale development and validation. Procedia- Social and Behavioral Sciences, 132, 203-208. https://doi.org/10.1016/j.sbspro.2014.04.299.

Sipahi, B., Yurtkoru, E. S. ve Çinko, M. (2010). Sosyal bilimlerde SPSS'le veri analizi (2. baskı). İstanbul: Beta Yayıncllık

Stampoltzis, A., Tsitsou, E. ve Papachristopoulos, G. (2018). Attitudes and intentions of Greek teachers towards teaching pupils with dyslexia: An application of the theory of planned behaviour. Dyslexia, 24, 128-139. http://doi.org/10. 1002/dys.1586.

Sümer Dodur, H. M. ve Altındağ Kumaş, Ö. (2021). Disleksi Bilgi ve İnanç Ölçeği'nin geçerlik ve güvenirlik çalışması. Kalem Eğitim ve İnsan Bilimleri Dergisi, 11(1) doi: 10.23863/kalem.2020.160.

Tabachnick, B. G. ve Fidell, L. S. (2013). Using multivariate statistics (6th ed.), Boston: Allyn and Bacon.

Wadlington, E. ve Wadlington, P. (2005). What educators really believe about dyslexia. Reading Improvement. Spring, 42(1)16-33.

Yıldız, M. ve Melekoğlu, M. A. (2020). Investigation of studies on reading comprehension skills of individuals with specific learning disabilities. Inonu University Journal of the Faculty of Education, 21(3), 1274-1303.

\section{Kaynakça Bilgisi / Citation Information}

Altındağ Kumaş, Ö. ve Sardohan Yıldırım, A. E. (2021). Öğretmenlerin Disleksili Öğrencilere Yönelik Öğretim Tutumları Ölçeği'nin geçerlik ve güvenirlik çalışması. OPUS- Uluslararası Toplum Araştırmaları Dergisi, 18(44), 8154-8171. DOI: 10.26466/opus.969139. 